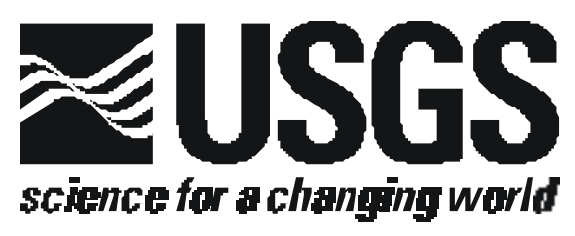

\title{
ANALYTICAL RESULTS FOR 35 MINE-WASTE TAILINGS CORES AND SIX BED-SEDIMENT SAMPLES, AND AN ESTIMATE OF THE VOLUME OF CONTAMINATED MATERIAL AT BUCKEYE MEADOW ON UPPER BASIN CREEK, NORTHERN JEFFERSON COUNTY, MONTANA
}

\author{
by David L. Fey ${ }^{1}$, Stanley E. Church ${ }^{1}$ and Christopher J. Finney ${ }^{1}$
}

Open-File Report 99-537

1999

This report is preliminary and has not been reviewed for conformity with U.S. Geological Survey editorial standards and stratigraphic nomenclature. Any use of trade, product, or firm names is for descriptive purposes only and does not imply endorsement by the U.S. Government.

U.S. DEPARTMENT OF THE INTERIOR

U.S. GEOLOGICAL SURVEY

${ }^{1}$ Denver, Colorado 


\section{Table of Contents}

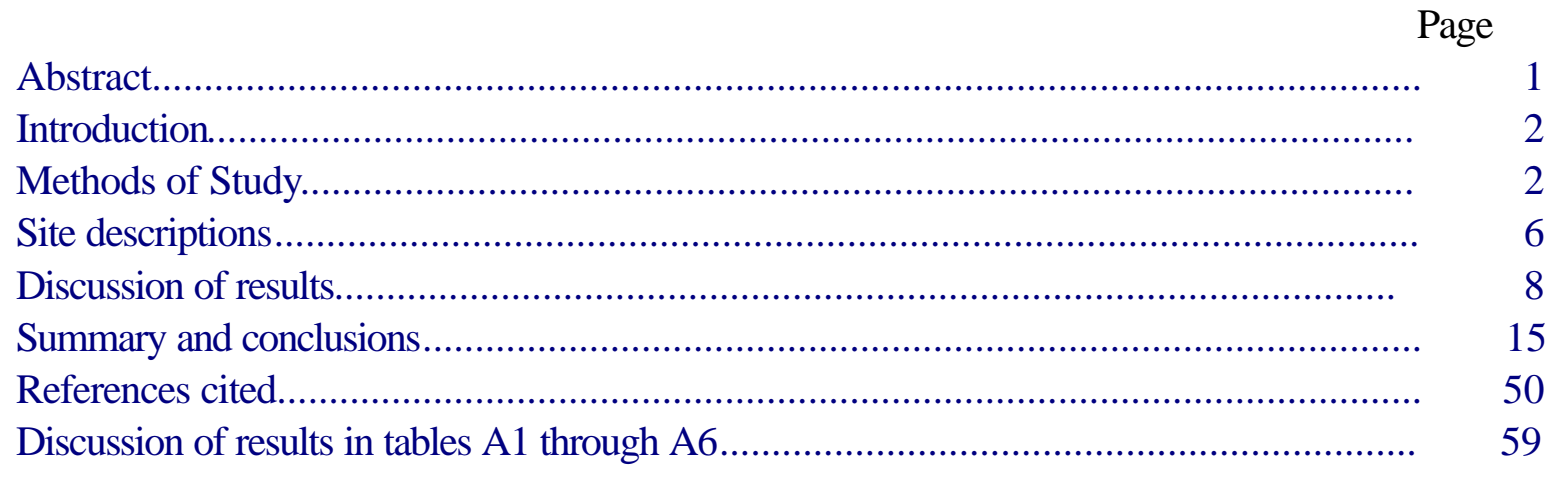

Figures

Figure 1. Location of Study Area and sample locality maps.................................... 3

Figure 2. Site configuration maps for tailings cores and bed sediments........................ 4

Figure 3 Thickness of contamination profile for main core traverse ............................. 10

Figure 4 Thickness of contamination profile for core traverse A................................ 10

Figure 5 Thickness of contamination profile for core traverse B.................................

Figure 6 Thickness of contamination profile for core traverse C................................ 11

Figure 7 Contour map of tailings area showing thickness of contamination...................... 14

\section{Tables}

Table 1. Coordinates of bed-sediment sites and core 98-BMF-102 ........................... 7

Table 2. Element concentration cutoff values for determination of contamination............ 8

Table 3. Thicknesses of contamination of tailings cores.........................................

Table 4. Core field numbers, depths of intervals, and interval sample descriptions....... 17

Table 5. Total-digestion concentrations for tailings core samples by ICP-AES............ 25

Table 6. Total-digestion concentrations for bed sediments by ICP-AES ..................... 47

Table 7. Analytical results for $2 \mathrm{M} \mathrm{HCl}-1 \% \mathrm{H}_{2} \mathrm{O}_{2}$ leach extraction of bed sediments.... $\quad 48$

Table 8. Total digestion concentrations for leach residues of bed sediments................ 49

\section{Appendix}

Table A1. Comparison of contract lab results with NIST values for SRM-2704......... 52

Table A2. Comparison of contract lab results with NIST values for SRM-2709......... 53

Table A3. Comparison of contract lab results with NIST values for SRM-2711......... 54

Table A4. Comparison of USGS lab results with NIST values for SRM-2704............ 55

Table A5. Comparison of USGS lab results with NIST values for SRM-2709........... 56

Table A6. Comparison of USGS lab results with NIST values for SRM-2711............ 57

Table A7. ICP-AES elements and their limits of determination............................... 58 


\begin{abstract}
$\underline{\text { ABSTRACT }}$
Metal-mining related wastes in the Boulder River basin study area in northern Jefferson County, Montana have been implicated in their detrimental effects on water quality with regard to acidgeneration and toxic-metal solubilization. Flotation-mill tailings in the meadow below the Buckeye mine, hereafter referred to as the Buckeye mill-tailings site, have been identified as significant contributors to water quality degradation of Basin Creek, Montana. Basin Creek is one of three tributaries to the Boulder River in the study area; bed sediments and waters draining from the Buckeye mine have also been implicated. Geochemical analysis of 35 tailings cores and six bed-sediment samples was undertaken to determine the concentrations of $\mathrm{Ag}, \mathrm{As}, \mathrm{Cd}, \mathrm{Cu}, \mathrm{Pb}$, and $\mathrm{Zn}$ present in these materials. These elements are environmentally significant, in that they can be toxic to fish and/or the invertebrate organisms that constitute their food. A suite of one-inch cores of dispersed flotation-mill tailings and underlying premining material was taken from a large, flat area north of Basin Creek near the site of the Buckeye mine. Thirty-five core samples were taken and divided into 204 subsamples. The samples were analyzed by ICP-AES (inductively coupled plasma-atomic emission spectroscopy) using a mixed-acid digestion. Results of the core analyses show that the elements listed above are present at moderate to very high concentrations (arsenic to 63,000 ppm, silver to $290 \mathrm{ppm}$, cadmium to $370 \mathrm{ppm}$, copper to 4,800 $\mathrm{ppm}$, lead to $93,000 \mathrm{ppm}$, and zinc to $23,000 \mathrm{ppm}$ ). Volume calculations indicate that an estimated 8,400 metric tons of contaminated material are present at the site. Six bed-sediment samples were also subjected to the mixed-acid total digestion, and a warm $\left(50^{\circ} \mathrm{C}\right) 2 \mathrm{M} \mathrm{HCl}-1 \% \mathrm{H}_{2} \mathrm{O}_{2}$ leach and analyzed by ICP-AES. Results indicate that bed sediments of Basin Creek are only slightly impacted by past mining above the Buckeye-Enterprise complex, moderately impacted at the upper (eastern) end of the tailings area, and heavily impacted at the lower (western) end of the area and downstream. The metals are mostly contained in the $2 \mathrm{M} \mathrm{HCl}-1 \% \mathrm{H}_{2} \mathrm{O}_{2}$ leachable phase, which are the hydrous amorphous iron- and manganese-hydroxide coatings on detrital sediment particles.
\end{abstract}




\section{INTRODUCTION}

Metal-mining related wastes in the Boulder River basin study area in northern Jefferson County, Montana have been implicated in their detrimental effects on water quality with regard to acid generation and toxic-metal solubilization during snow melt and storm water runoff events (Buxton and others, 1997). The bed sediments and waters of Basin Creek have been impacted by contamination from mine waste and tailings from the Buckeye-Enterprise mining and milling complex (Metesh and others, 1994). Basin Creek is one of three major tributaries to the Boulder River in the study area, (see figure 1) and is a contributor to water quality degradation of the Boulder River. During the late 1800's and early 1900's, the Buckeye and the Enterprise mines were worked together, and both used an on-site gravity mill to concentrate ore. The mined ore contained pyrite, arsenopyrite, galena, sphalerite, and tourmaline. During World War II, a flotation mill was built in the floodplain of Basin Creek to re-process the gravity tailings from the old mill (Metesh and others, 1994). The Buckeye-Enterprise mine/mill complex was assessed for possible listing in the National Register of Historic Places; such listing could affect reclamation actions. As a result of the collapsed state of most of the mining related structures, and lack of significant architectural or engineering features, the complex was not recommended for listing. (Rossillon and Haynes, 1999). The mass of the reprocessed flotation tailings was estimated at 16,000 tons (Metesh and others, 1994). These tailings have dispersed over a wide area (about 3.3 acres) whose southern edge is bounded by Basin Creek. Desborough and Fey (1997) studied waste material from nine mine sites in the Basin district and produced a qualitative scale for potential water-quality degradation resulting from these wastes. The scale was based on the combined effect of acid-generation potential, dissolved toxic metals from a passive leach, and estimated tonnage. Tailings produced by the flotation mill process in the floodplain of Basin Creek scored a nine on a scale of one (low) to nine (high). These tailings are the subject of this investigation. This report presents analytical results for totaldigestion elemental content for 35 cores, and the total-digestion elemental content, leachable elemental content, and the total-digestion elemental content of leach residues for six stream sediments. A similar report covered the fluvial tailings present in High Ore Creek, downstream from the Comet mine (Fey and Church, 1998).

\section{METHODS OF STUDY}

\section{$\underline{\text { Sample Collection }}$}

All samples were collected from or near Basin Creek, (T8N R6W Section 36) located on the Three Brothers, Montana USGS 1:24,000 topographic map.

\section{Stream sediments}

In October 1996, we collected 47 bed-sediment samples in the Boulder River basin, including one from Basin Creek west and outside of the Buckeye tailings study area. In July 1997, we collected four additional bed-sediment samples from Basin Creek on the eastern and south- ern edges of the tailings area. In July 1998, we collected one additional bed-sediment sample on Basin Creek upstream of the tailings area and mine workings, for a total of six bed sediments from the Buckeye tailings site (figure 2). Analyses of bed-sediment samples represent the chem- 

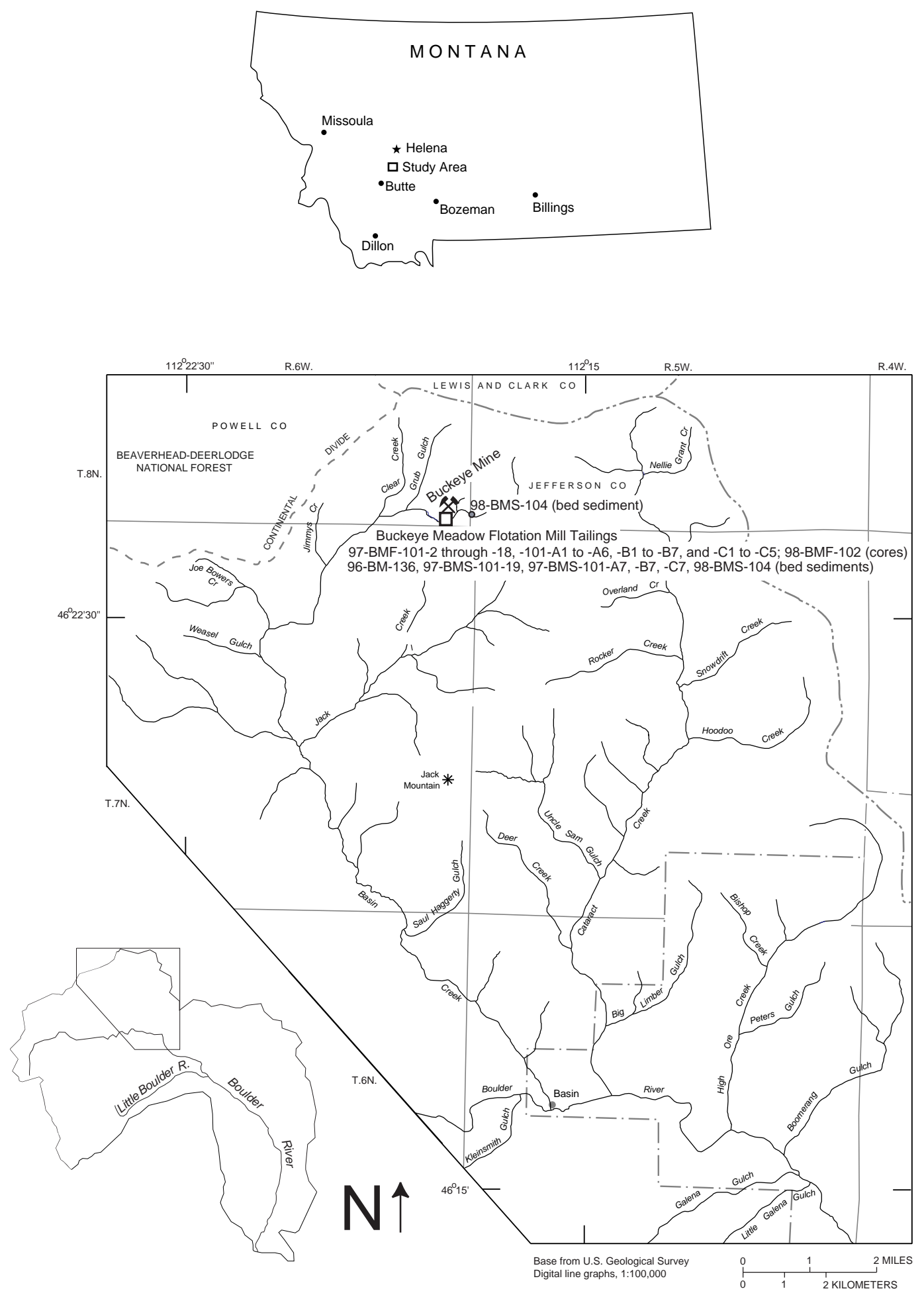

Figure 1. Index map of Montana showing Boulder River study area and sample locality map for flotation mill-tailings cores and bed sediments from Buckeye meadow area 


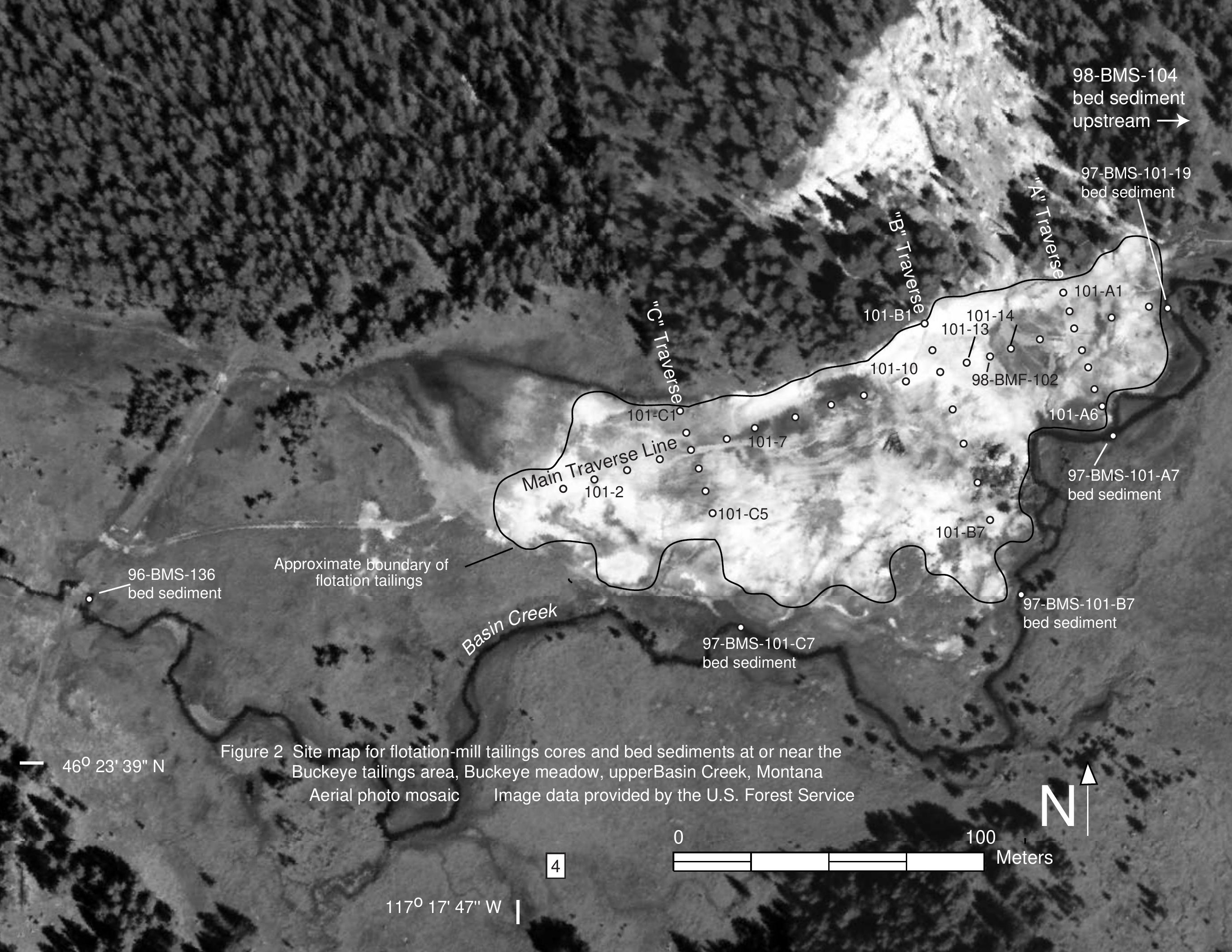


istry of material eroded upstream of the sample site and from colloidal material coating the detrital grains. An integrated bed-sediment sample was collected at each site by compositing 10 to 20 individual subsites within $15 \mathrm{~m}$ (50 ft.) of the plotted site, and collecting material from the active channel alluvium. In the field, each composited sample was sieved through a $2 \mathrm{~mm}$ (10 mesh) stainless steel screen, and the minus- $2 \mathrm{~mm}$ fraction retained; the larger fractions were discarded.

\section{$\underline{\text { Fluvial Tailings Cores }}$}

In July 1997, we collected a suite of 34 one-inch diameter cores from the north flood plain of Basin Creek (not the active stream channel). This suite is identified as 97-BMF-101. The samples were collected along a traverse bearing $\mathrm{N} 74^{\mathrm{O}} \mathrm{E}$ for approximately 200 meters (650 feet) starting from the west end of the tailings area, and from three traverses (A, B, and C) perpendicular to the main line (figure 2). All samples were collected in plastic core tubes using a stainless-steel soil probe/sampler to depths up to $65 \mathrm{~cm}$, the maximum penetration of a single probe. Typical depths were 50 to $60 \mathrm{~cm}$. Core penetration depth and actual length were recorded on-site to determine the amount of compression. An additional core was collected from the bottom of a four-foot-deep trench in July 1998. The configuration of the site, core locations, and traverses are shown in figure 2.

\section{Sample Preparation}

$\underline{\text { Stream-sediment samples }}$

Bed-sediment samples were dried at ambient room temperature $\left(25^{\circ} \mathrm{C}\right)$ and sieved to minus80-mesh $(<.18 \mathrm{~mm})$ prior to laboratory analyses.

Flotation-tailings-core samples

Core samples were subdivided in the laboratory into subsamples (by depth) according to visual identification of differences in mineralogy, organic content, and apparent oxidation zones. See table 4 for subsample descriptions and their depths within cores. A core compaction factor was incorporated to determine the actual depth of the subsamples; the assigned depth for each is defined as the midpoint of that subsample. The cores were subdivided into two to ten subsamples, typically about five. These subsamples were then placed in a random order and ground using a vertical pulverizer with ceramic plates to minus $100-$ mesh $(<0.15 \mathrm{~mm})$. Thirty-four cores were collected from site $97-\mathrm{BMF}-101$ and these were divided into 196 subsamples. The core from 1998, 98-BMF-102, was divided into eight subsamples.

\section{Sample Analysis}

Total digestion ICP analysis for 32 elements

The six bed-sediment samples, leach residues for the six bed-sediment samples from the partial extraction described below, and 204 core subsamples were digested with a mixed-acid procedure consisting of $\mathrm{HCl}, \mathrm{HNO}_{3}, \mathrm{HClO}_{4}$, and $\mathrm{HF}$, and analyzed for 32 elements by ICP-AES (inductively coupled plasma-atomic emission spectroscopy) (Crock and others, 1983; Briggs, 1996). This procedure is effective in dissolving most minerals, including silicates, oxides and sulfides; resistant or refractory minerals such as zircon, chromite, and some tin oxides are only partially dissolved. Previous investigations using 
a variety of materials support the completeness of the digestion (Church and others, 1987; Wilson and others, 1994). The values for total-digestion analyses for the cores are given in table 5, and the values for total-digestion analyses for the bed sediments are given in table 6. Limits of determination for the total digestion method are given in table A7 in the Appendix. Comparisons of values observed for three National Institute of Standards and Technology (NIST) standard reference materials (SRM-2704, SRM-2709 and SRM-2711) with certified values (NIST, 1993a, 1993b, and 1993c) are given in table A1, table A2, table A3, table A4, table A5, and table A6 in the Appendix.

\section{Warm $2 \mathrm{M} \mathrm{HCl}-1 \% \mathrm{H}_{2} \underline{\mathrm{O}}_{2}$ leach extraction}

The use of a partial-digestion extraction enables one to determine concentrations of trace elements bound within different phases, whereas a total digestion releases all trace elements in a sample (Chao, 1984). The six bed sediments from Basin Creek were subjected to a partial-digestion extraction consisting of warm $\left(50^{\circ} \mathrm{C}\right) 2 \mathrm{M} \mathrm{HCl}-1 \% \mathrm{H}_{2} \mathrm{O}_{2}$ for three hours with continuous agitation; the leachates were subsequently analyzed by ICP-AES for 29 elements. This partial extraction releases trace elements associated with hydrous amorphous iron- and manganese-oxide mineral coatings and colloidal particles (Appendix III of Church and others, 1993; Church and others, 1997). Mineral coatings such as those observed in Basin Creek can contain a significant percentage of the trace elements in a sample (Church and others, 1997). The residues from this extraction were then dried, weighed, and subjected to the total digestion described above to determine trace element concentrations bound in the oxide, silicate, and more-resistant sulfide phases. The data obtained from the $2 \mathrm{M} \mathrm{HCl}-1 \% \mathrm{H}_{2} \mathrm{O}_{2}$ extraction are presented in table 7 , and the data for the total digestion of the residues are given in table 8. Analytical limits of determination for the partial-digestion leach method are given in table A7 in the Appendix.

\section{$\underline{\text { Site Descriptions }}$}

\section{$\underline{\text { Stream sediments }}$}

Locations of the bed-sediment sample sites are given in table 1 and are shown on figure 2 Bed-sediment sample 96-BM-136 is located downstream of the tailings area, just east of a 4WD road that crosses Basin Creek. Sample sites 97-BMS-101-C7, -B7, and -A7 are located on Basin Creek, where the three perpendicular core traverses meet with the creek. Site 97-BMS-101-19 is located on the creek, at the far eastern end of the tailings area, and where the main core traverse meets the creek. Site 98-BMS-104 is located upstream from the Buckeye mine, about $0.2 \mathrm{~km}$ (700 ft.) east of the confluence of Basin Creek with a small, unnamed northern tributary.

\section{Flotation-tailings cores}

The locations of the flotation-tailings cores and the configuration of the traverses are shown in figure 2. Seventeen core samples (cores 97-BMF-101-2 through -101-18) were collected from the main traverse, spaced 12 meters (40 feet) apart. No core was taken at site 1, as tailings material was essentially absent at that point. The tailings are thickest $(1.2 \mathrm{~m}$ or $4 \mathrm{ft})$ near the eastern part of the area, which consists of a topographic high. The topographic high is located between sites 97-BMF-101-13 and $-101-14$, about $60 \mathrm{~m}(200 \mathrm{ft})$ southwest of the sediment site 97-BMS-101-19, along the main sampling traverse. This point corresponds to the location of core 98-BMF-102 
Traverse $A$ is perpendicular to and crosses the main traverse between sites 15 and 16, and, along a bearing of $\mathrm{N}^{\circ} 6^{\circ} \mathrm{W}$. There are six samples from traverse A, starting at the upper (north) end. Two cores were collected north of the main traverse, and four cores were collected south of the main traverse. The spacing between these cores was $6 \mathrm{~m}(20 \mathrm{ft})$, except between 97-BMF-101A2 and 101A3, which were $12 \mathrm{~m}$ (40 ft) apart; no core was taken at the intersection of traverse $\mathrm{A}$ and the main traverse.

Traverse B crosses the main line at site 97-BMF-101-12. Traverse B is also perpendicular to the main traverse, and has the same bearing as Traverse A. The spacing between cores was $12 \mathrm{~m}$ (40 $\mathrm{ft})$. Two cores (97-BMF-101B1 and -101B2) were collected north of the main line, and four cores (97-BMF-101B4 through -101B7) south of the main line. Site 97-BMF-101B3 is the same as the main traverse site 97-BMF-101-12, and so a second core was not taken at this site.

Traverse $\mathrm{C}$ is located near the western end of the main traverse, crossing at site 97-BMF-1015. It is also perpendicular and has the same bearing as traverses A and B. Two cores (97-BMF$101 \mathrm{C} 1$ and -101C2) were collected north of the main line, and three (97-BMF-101C3, -101C4 and 101C5) were collected south of the main line. The spacing between cores on traverse $\mathrm{C}$ was $6 \mathrm{~m}$ (20 $\mathrm{ft}$ ), except between 97-BMF-101C2 and C3, which was $12 \mathrm{~m} \mathrm{(40} \mathrm{ft).} \mathrm{As} \mathrm{with} \mathrm{traverse} \mathrm{B,} \mathrm{a} \mathrm{second}$ (duplicating) core was not collected from the intersection of traverse $\mathrm{C}$ with the main line. The depths of each core subinterval, along with sample descriptions for each subsample, are given in table 4.

In July 1998, we dug trenches through the tailings with a track-mounted backhoe at several bcations on the tailings area. The purpose of digging these trenches was to determine the depth of tailings, especially through the thickest section where sample cores from 1997 did not penetrate through the bottom, and to sample the lower part of the tailings. We took a core (98-BMF-102) from the bottom of one four-foot-deep trench that was located essentially at the high part of the topographic mound, the thickest part of the tailings. The subsample descriptions and depths for this core are also presented in table 4.

Table 1. Localities of bed-sediment sites and core 98-BMF-102, in decimal degrees.

\begin{tabular}{|lll|}
\hline Bed Sediment & & \\
Field Number & N. Latitude & W. Longitude \\
\hline 96-BM-136 & 46.39471 & 112.29825 \\
97-BMF-101-C7 & 46.39463 & 112.29557 \\
97-BMF-101-B7 & 46.39472 & 112.29436 \\
97-BMF-101-A7 & 46.39520 & 112.29398 \\
97-BMF-101-19 & 46.39557 & 112.29374 \\
98-BMS-104 & 46.39611 & 112.28944 \\
\hline $\begin{array}{l}\text { Site 98-BMF-102, post site at } \\
\text { high point of tailings mound }\end{array}$ & 46.39541 & 112.29450 \\
\hline
\end{tabular}

\section{Discussion of Results}

\section{$\underline{\text { Tailings Cores }}$}


Examination of total digestion data (table 5) reveals that the majority of the core samples contain contamination from the environmentally important elements $\mathrm{Ag}, \mathrm{As}, \mathrm{Cd}, \mathrm{Cu}, \mathrm{Pb}$, and $\mathrm{Zn}$. Along the main traverse, the maximum concentrations (in ppm) for the elements listed above are: silver 290; arsenic 63,000 (6.3\%); cadmium 370; copper 4800; lead 93,000 (9.3\%); zinc 28,000 (2.8\%). Along traverse A, the maximum concentrations (in ppm) for the elements listed above are: silver 100; arsenic 23,000 (2.3\%); cadmium 130; copper 470; lead 17,000 (1.7\%); zinc 420. Along Traverse B, the maximum concentrations (in ppm) for the listed elements are: silver 180; arsenic 24,000 (2.4\%); cadmium 130; copper 390; lead 31,000 (3.1\%); zinc 460. Along Traverse C, the maximum concentrations (in ppm) for the listed elements are: silver 150; arsenic 38,000 (3.8 \%); cadmium 200; copper 1,200; lead 26,000 (2.6\%); zinc 530. In addition to the high concentrations of these trace elements, there is generally attenuation of the trace elements with depth. However, several cores, notably 97BMF-101-13, 97-BMF-101-14, and 97-BMF-101-B1, do not penetrate below the level of contamination. This is illustrated by the failure of silver and lead to diminish by the cores' bottoms.

The subsample descriptions presented in table 4 generally include the depths in the cores where the samples contain sandy material with either fresh or oxidized micas. This material is sediment deposited by a meandering stream, and includes unmineralized material derived from the Butte quartz monzonite (oral commun., J. M. O'Neill, 1999). This stream deposit is often capped by a soil horizon, upon which the tailings were deposited. The depth to which the actual tailings material extends can be estimated by the behavior of silver, which is relatively immobile in these tailings cores. The depth at which the concentration of silver was not detected generally corresponds to the depth at which micas (and hence pre-tailings stream sand) are present. Some of the uppermost core samples also include the presence of micas, although this is probably the result of later sandy material being transported onto and mixed with the upper tailings. Numerous subsamples at depth contain charcoal and/or other organic matter, also indicating that these samples are below the original level of tailings.

The depth of contamination is deeper than the depth of the original tailings, as a result of the downward migration of trace elements from the tailings. This is illustrated most clearly by the downward decreases in concentrations of arsenic, cadmium, copper, and zinc. Lead, however, behaves in a fashion similar to silver, in that its concentrations do show significant attenuation with depth. We determined the depths of contamination based on the values shown below in table 2. These limits are operationally defined, and are approximately 10 to 50 times the crustal abundance concentrations. Note that the regional background values for lead and zinc are higher than crustal abundance. Crustal abundance data are from Fortescue (1992) and the regional background values are from our unpublished work in the Boulder study area.

Table 2 Element concentration cutoff values for determination of contamination

\begin{tabular}{|l|c|c|c|c|c|}
\hline Element & $\mathrm{Ag}$ & $\mathrm{Cd}$ & $\mathrm{Cu}$ & $\mathrm{Pb}$ & $\mathrm{Zn}$ \\
\hline Cut-off value & $5 \mathrm{ppm}$ & $5 \mathrm{ppm}$ & $300 \mathrm{ppm}$ & $100 \mathrm{ppm}$ & $500 \mathrm{ppm}$ \\
\hline Crustal abundance & $0.08 \mathrm{ppm}$ & $0.16 \mathrm{ppm}$ & $68 \mathrm{ppm}$ & $13 \mathrm{ppm}$ & $76 \mathrm{ppm}$ \\
\hline Ratio & 62 & 31 & 4.4 & 8 & 7 \\
\hline Regional background & $<2 \mathrm{ppm}$ & $<2 \mathrm{ppm}$ & $30 \mathrm{ppm}$ & $55 \mathrm{ppm}$ & $170 \mathrm{ppm}$ \\
\hline
\end{tabular}


Arsenic concentration was not used in the determination of the depth of contamination. Athough arsenic levels often diminish with depth in these samples, the concentrations in some cores, particularly from the eastern half of the tailings area, remain high (table 5). In those cores, far greater depths would be required to reach regional baseline levels of arsenic. Bed sediments collected at and downstream of the tailings complex also show high arsenic levels (up to 4,500 ppm, as shown in table 6). However, despite the high concentrations of arsenic in the core material, their proximity to Basin Creek, and the high arsenic concentrations in the bed sediments, soluble arsenic in the stream water at low flow is not elevated. Metesh and others (1994, Appendix V) reported $2.4 \mu \mathrm{g} / \mathrm{L}(\mathrm{ppb})$ arsenic in stream water collected above the Buckeye-Enterprise complex, and $20 \mu \mathrm{g} / \mathrm{L}$ arsenic in stream water collected below the mines and tailings. Neither value exceeds EPA primary or secondary drinking water standards, or EPA chronic or acute aquatic life standards (Metesh and others, 1994, table 18). In contrast, concentrations in the stream-water sample collected below the mines and tailings did exceed the EPA chronic aquatic life standards for copper, lead, and zinc (Metesh and others, 1994, table 18). Therefore we used concentrations of copper, lead, and zinc, as well as silver and cadmium, but not arsenic, to delineate depth of contamination.

We used the element cutoffs to determine contamination depths by inspecting where each core's trace-metal values were all below the cutoffs; if any one of the five trace elements exceeded the cutoff, that core interval was considered contaminated. Table 3 presents the depths of contamination for each core as described. The profiles of the depths to the bottom of tailings, as determined by silver concentrations and the appearance of micaceous sand in the sample descriptions (dashed line), and the depths to bottom of contamination, as determined by the concentrations of cadmium, copper, lead, and zinc (solid line), are shown in figure 3, figure 4, figure 5, and figure 6.

Table 3 Thicknesses of contamination of tailings cores.

\begin{tabular}{|lccc|}
\hline Core Number & $\begin{array}{c}\text { Contamination } \\
\text { thickness, cm }\end{array}$ & Core Number & $\begin{array}{c}\text { Contamination } \\
\text { thickness, cm }\end{array}$ \\
\hline 97BMF-101-2 & 57 & 97BMF-101-A1 & 23 \\
97BMF-101-3 & 41 & 97BMF-101-A2 & 53 \\
97BMF-101-4 & 23 & 97BMF-101-A3 & 51 \\
97BMF-101-5 & 21 & 97BMF-101-A4 & 83 \\
97BMF-101-6 & 60 & 97BMF-101-A5 & 52 \\
97BMF-101-7 & 59 & 97BMF-101-A6 & 39 \\
97BMF-101-8 & 45 & 97BMF-101-B1 & 30 \\
97BMF-101-9 & 27 & 97BMF-101-B2 & 43 \\
97BMF-101-10 & 42 & 97BMF-101-B4 & 55 \\
97BMF-101-11 & 61 & 97BMF-101-B5 & 45 \\
97BMF-101-12 & 63 & 97BMF-101-B6 & 15 \\
97BMF-101-13 & 120 & 97BMF-101-B7 & 22 \\
98BMF-102 & 160 & 97BMF-101-C1 & 64 \\
97BMF-101-14 & 120 & 97BMF-101-C2 & 40 \\
97BMF-101-15 & 85 & 97BMF-101-C3 & 26 \\
97BMF-101-16 & 65 & 97BMF-101-C4 & 31 \\
97BMF-101-17 & 75 & 97BMF-101-C5 & 72 \\
97BMF-101-18 & 28 & & \\
\hline
\end{tabular}




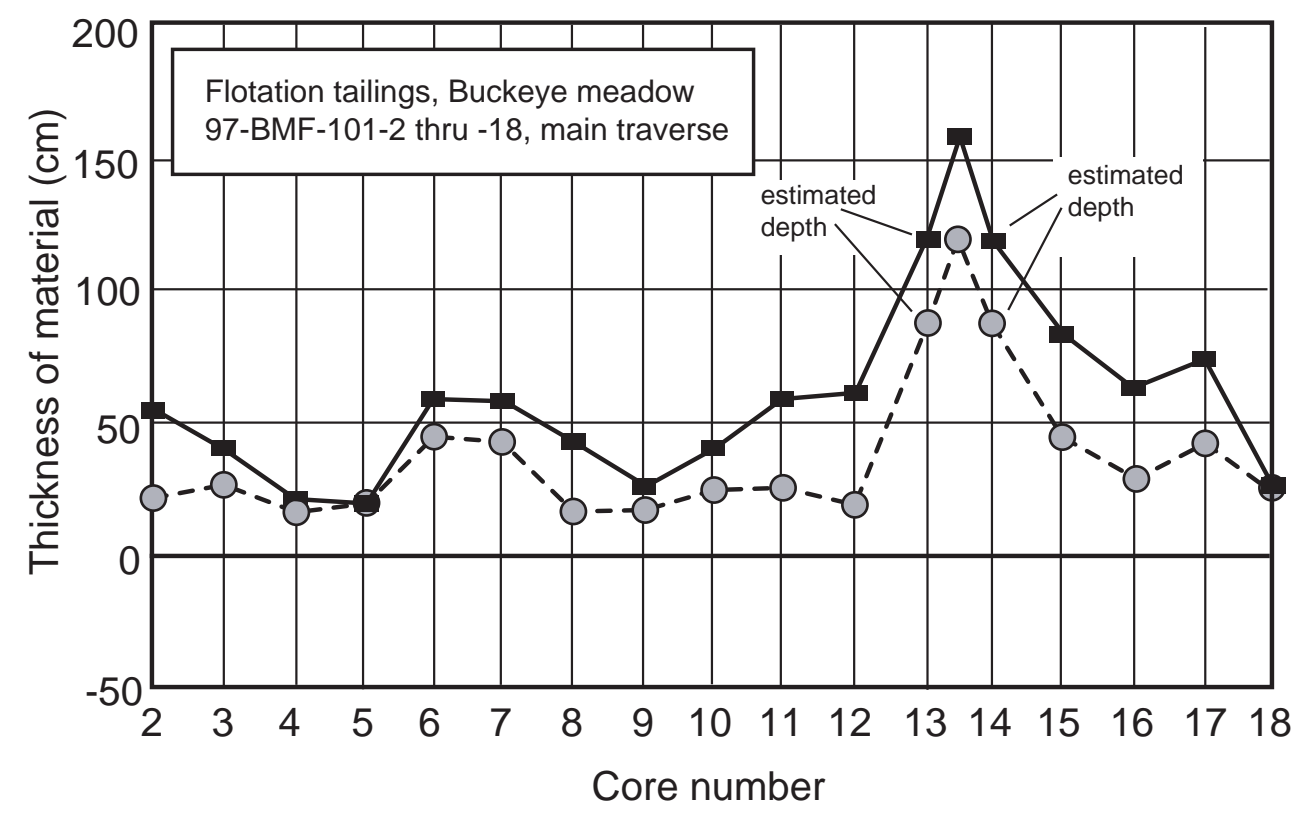

Figure 3. Thickness of tailings (dashed line and gray circles) and thickness of contamination (solid line and black squares) along main traverse line. Depths are estimated at cores 97-BMF-101-13 and -14 .

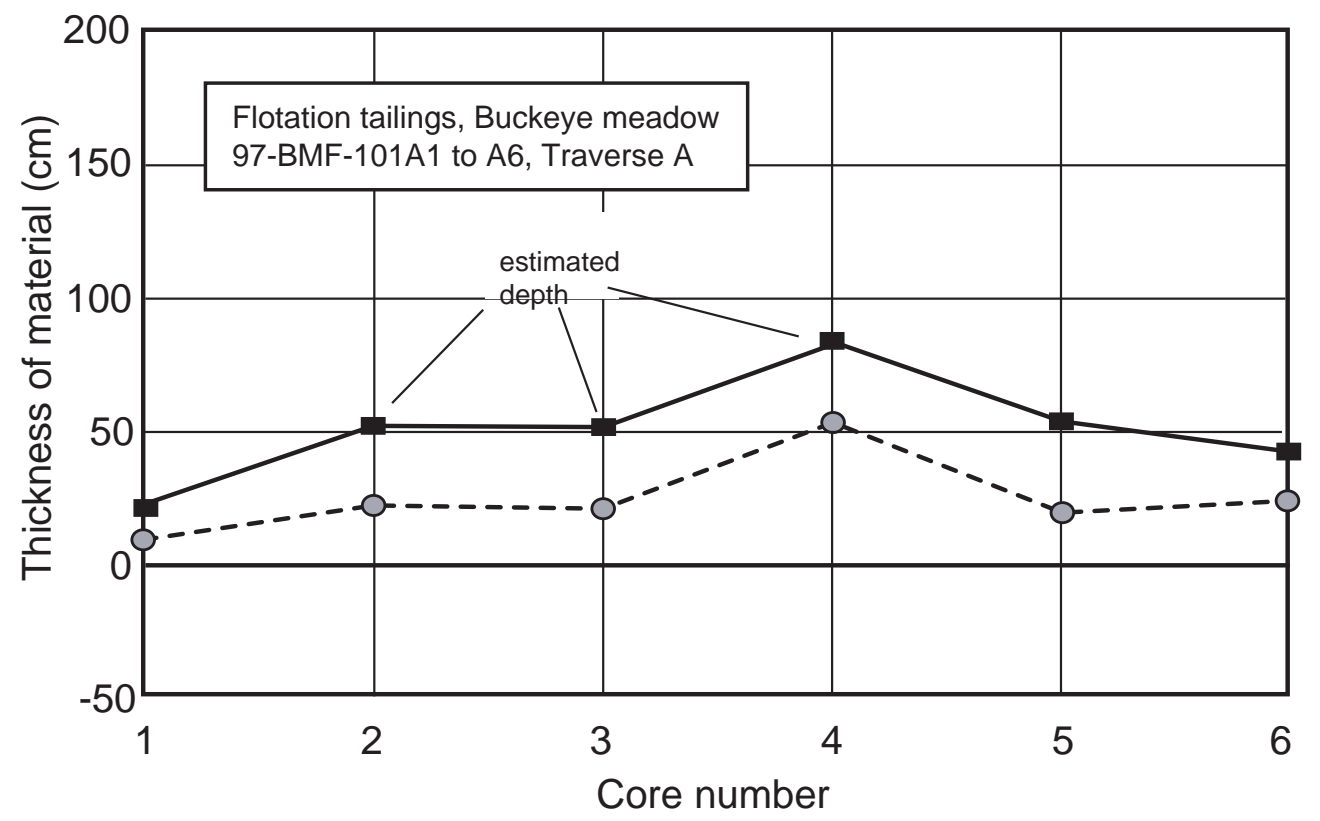

Figure 4. Thickness of tailings (dashed line and gray circles) and thickness of contamination (solid line and black squares) along traverse A. Depths are estimated at cores 97-BMF-101-A2, -A3, and -A4. 


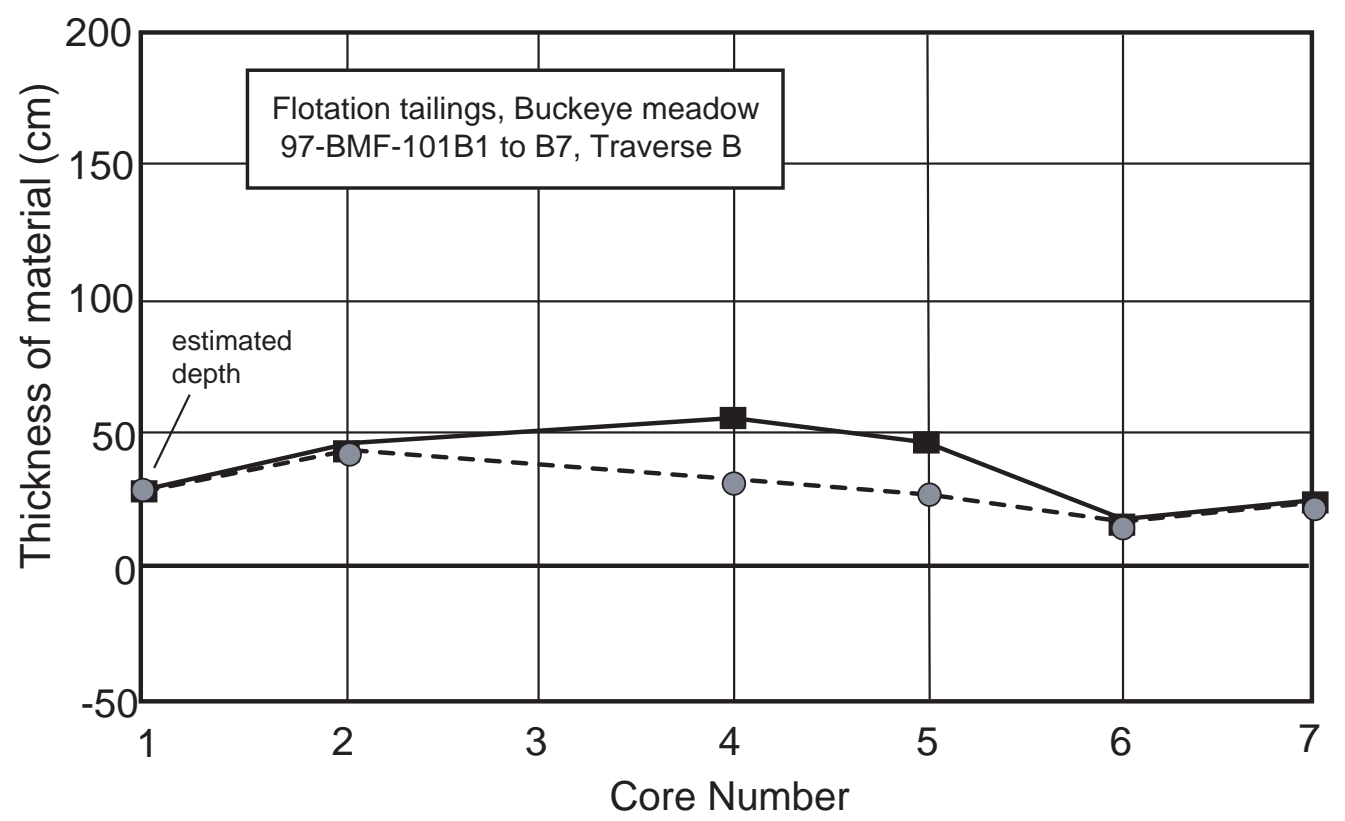

Figure 5. Thickness of tailings (dashed line and gray circles) and thickness of contamination (solid line and black squares) along traverse B. Depth is estimated at core 97-BMF-101-B1.

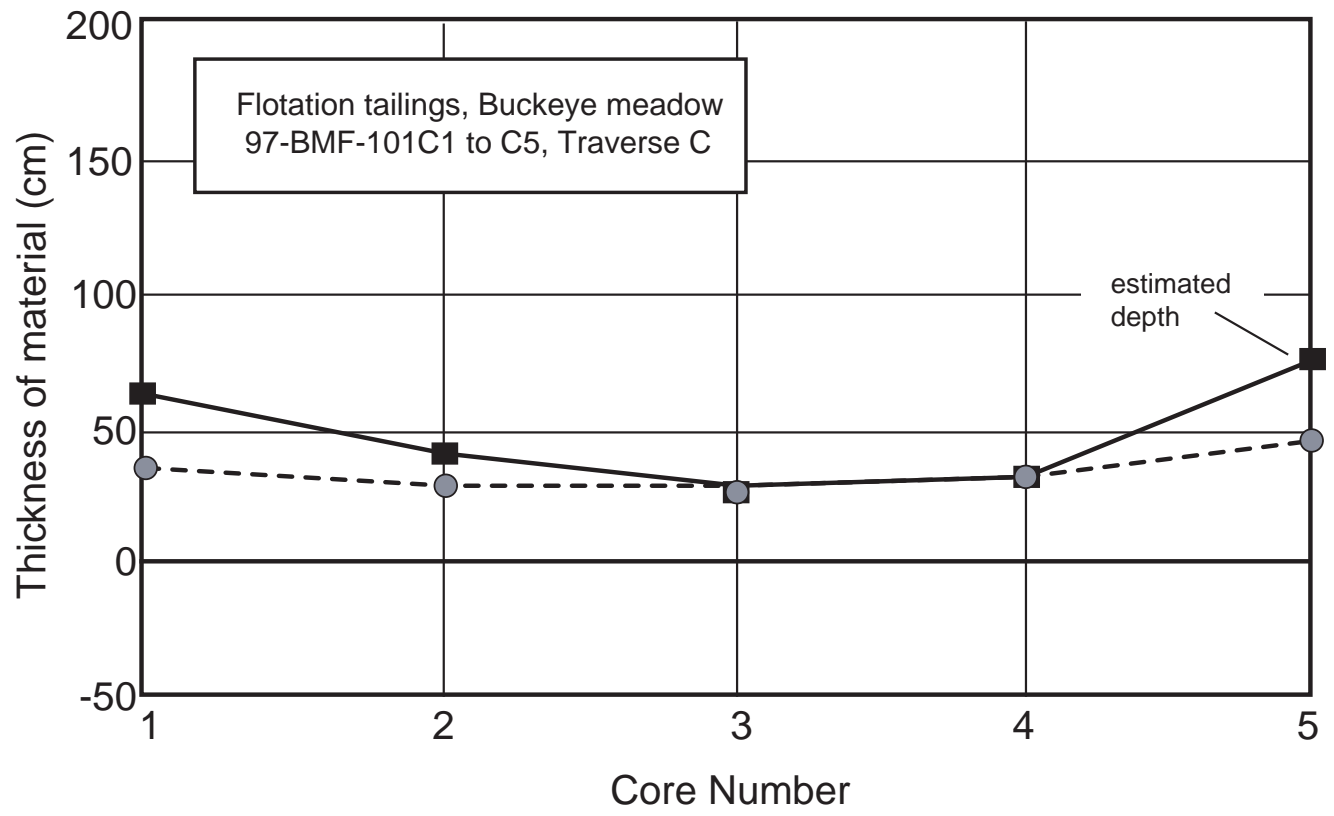

Figure 6. Thickness of tailings (dashed line and gray circles) and thickness of contamination (solid line and black squares) along traverse C. Depth is estimated at core 97-BMF-101-C5. 
Main tailings traverse, cores 97-BMF-101-2 through 101-18

The profiles of the depth to bottom of tailings and the depth to the bottom of contamination for the main traverse line are shown in figure 3. The old soil horizon, or alternatively the original horizon marking the top of the micaceous sand, is probably relatively flat and planar, with the variation in depth profile related to the thickness of the tailings deposited on top of this sand. When the depths are plotted relative to a flat, planar datum, as shown in figure 3, the profile essentially reflects the topographic expression of the tailings at the surface. The datum chosen here is the average level at which the cores reached the micaceous sand layer between cores 2 and 5, about $24 \mathrm{~cm}(0.8 \mathrm{ft}$.). This is shown as the heavy horizontal line in figure 3. The tailings are generally quite shallow at the west end of the traverse, having a depth of less than $30 \mathrm{~cm}$ (1 ft.) between cores 2 and 5 . The depth of contamination for the first four cores is between 20 and $60 \mathrm{~cm}(0.7$ to $2 \mathrm{ft})$. The depth to the bottom of the tailings and the bottom of contamination increases at cores 6,7 and 8 , most likely due to topographic thickening. The thickness decreases at core 9, and then increases again between cores 10 and 12. The greatest thickness occurs between cores 13 and 14. These cores, taken from the surface in 1997, did not penetrate to the bottom of tailings or contamination. The subsequent core taken in 1998 (98-BMF-102) from the bottom of the four-foot-deep trench, located approximately at the high point of the topographic mound, and between cores 13 and 14, did penetrate through the tailings and trace-element migration-related contamination. This defines the deepest and thickest zone of tailings, and the deepest level of contamination of about $160 \mathrm{~cm}(5.2 \mathrm{ft}$.).

Cores 15 through 17 did penetrate to below the level of silver, but did not reach the base of contamination as a result of downward trace-element migration. The depths of contamination for these cores are estimated based on their proximity to core 98-BMF-102, and the general trend seen in other cores for the distance to which contamination persists below the silver occurrences, about $30 \mathrm{~cm}(1 \mathrm{ft}$.). Core 97-BMF-101-18 was the easternmost core taken, about six meters ( $20 \mathrm{ft}$ ) from the bank of Basin Creek. The thickness of the tailings and contaminated material here was only about $18 \mathrm{~cm}(0.6 \mathrm{ft}$.).

Perpendicular traverses, 97-BMF-101A, 101B, and 101C

Traverse $\mathrm{A}$ is located near the east end of the main traverse, and intersects the main traverse at core 16 (see figure 2). Figure 4 shows the thickness profile for this traverse. The thicknesses of contamination for cores 97-BMF-101-A2, -A3, and -A4 are estimated, since the cores' maximum penetrations did not reach below the contamination zone. The contamination thicknesses for these cores are also estimated to extend about $30 \mathrm{~cm}(1 \mathrm{ft}$.) below the deepest silver occurrences. Figure 4 shows that the tailings and contamination thicknesses are least at the north end of the traverse, near the break in slope to the quartz monzonite hill, greater in the center, and are less again at the south end of the traverse. The thickness at station -A6 is, however, $39 \mathrm{~cm}$ (1.3 ft.).

Traverse B is also perpendicular to the main traverse, and intersects the main traverse at core 97-BMF-101-12. The contamination depth profile is shown in figure 5. The first core, 97-BMF-101$\mathrm{B} 1$, was only $19 \mathrm{~cm}$ in depth and was clearly tailings material to the bottom, as reflected by a silver content of $180 \mathrm{ppm}$ in the lowest subsample. This core probably reached bedrock at shallow depth, near the break in slope to the north. We have assigned an estimated maximum potential depth of contamination of $30 \mathrm{~cm}(1 \mathrm{ft}$.) for this core. The contamination reaches a moderate thickness of $55 \mathrm{~cm}(1.8$ ft.) at core 97-BMF-101-B4, and then thins again to the south. 
Traverse $\mathrm{C}$ is towards the western end of the main traverse, and intersects the main traverse at core 97-BMF-101-5. The contamination depth profile is shown in figure 6. Core 97-BMF-101-C5, at the southern end of traverse $\mathrm{C}$, did not penetrate through the bottom of contamination, and the depth shown is estimated, as before, from the general trend seen in other cores.

\section{Estimate of volume of tailings}

The areal extent of the flotation mill tailings at the Buckeye mine is estimated at about $13,000 \mathrm{~m}^{2}$ $\left(140,000 \mathrm{ft}^{2}\right.$ or about 3.3 acres). Using the values for thickness of contamination for all the cores, a simple contour map of the area can be constructed (figure 7) and the contour interval thicknesses integrated with their areal extent to obtain the total volume affected by contamination. The contamination thicknesses from Table 3 were arranged in increasing order, and assigned to one of five classes, A-E. The classes were assigned thicknesses that represented an approximation of the average for those cores contained in it. Nine cores had thicknesses in the "A" class $(25 \mathrm{~cm})$, fifteen in the "B" class $(50 \mathrm{~cm})$, four in the "C" class $(65 \mathrm{~cm})$, four in the "D" class $(80 \mathrm{~cm})$, and three in the "E" class $(140 \mathrm{~cm})$. The symbols were then plotted on the site map, and contours developed to estimate areas of similar thickness. For the area beyond the "A" contour, but within the approximate boundary of tailings, a value of $10 \mathrm{~cm}$ was used to represent the thickness (area shown marked by "X's"). This designation was for use in estimating volumes, only; the sites marked with " $\mathrm{X}$ ' $\mathrm{s}$ " do not represent actual core sites or thickness measurements. In addition, the contours developed are also approximations for use in volume estimates, and are not meant to indicate actual thicknesses. Their positions and values along the four traverses are good estimates, but since the sampling plan is not a true grid, the contour positions far from actual core sites (as in the large area between traverses B and C and south of the main traverse) are necessarily rough approximations. The areal extent of each class is as follows: class $\mathrm{X}, 5,250 \mathrm{~m}^{2}$; class A, 4,200 $\mathrm{m}^{2}$; class B, 2,600 $\mathrm{m}^{2}$; class C, $700 \mathrm{~m}^{2}$; class D, $410 \mathrm{~m}^{2}$; and class E, $120 \mathrm{~m}^{2}$. The sum of the products of the class areas and depths yields a total volume estimate of 3,800 cubic meters, or 5,000 cubic yards. Using an average value for density of the core material of $2.2 \mathrm{~g} / \mathrm{cm}^{3}$, a calculation for mass yields an estimate of 8,400 metric tons.

\section{Bed sediments}

The analytical data derived from the stream sediments clearly show contribution of traceelements from the tailings (table 6). The uppermost sample taken, above the Buckeye-Enterprise mine complex and tailings (98-BMS-104), has total-digestion concentrations of the six elements As, Ag, Cd, $\mathrm{Cu}, \mathrm{Pb}$, and $\mathrm{Zn}$, at or near the regional uncontaminated geochemical baseline values, with little influence from prospects farther upstream. Sample 97-BMS-101-19, from Basin Creek at the far eastern edge of the tailings, shows slight elevations in concentrations. Sample 97-BMS-101-A7 shows the beginning of influence from the tailings, mostly as increased arsenic and lead concentrations. Samples 97-BMS101-B7, -C7, and 96-BM-136 all show marked increases in concentrations. Basin Creek probably receives tailings between 97-BMS-101-19 and 97-BMS-101-A7 mostly as material that sloughs off the banks. West of the thick topographic mound centered on 98-BMF-102, the tailings gently slope to the south, and are dissected by surface drainage channels. Sheet flow and surface runoff during storm events 


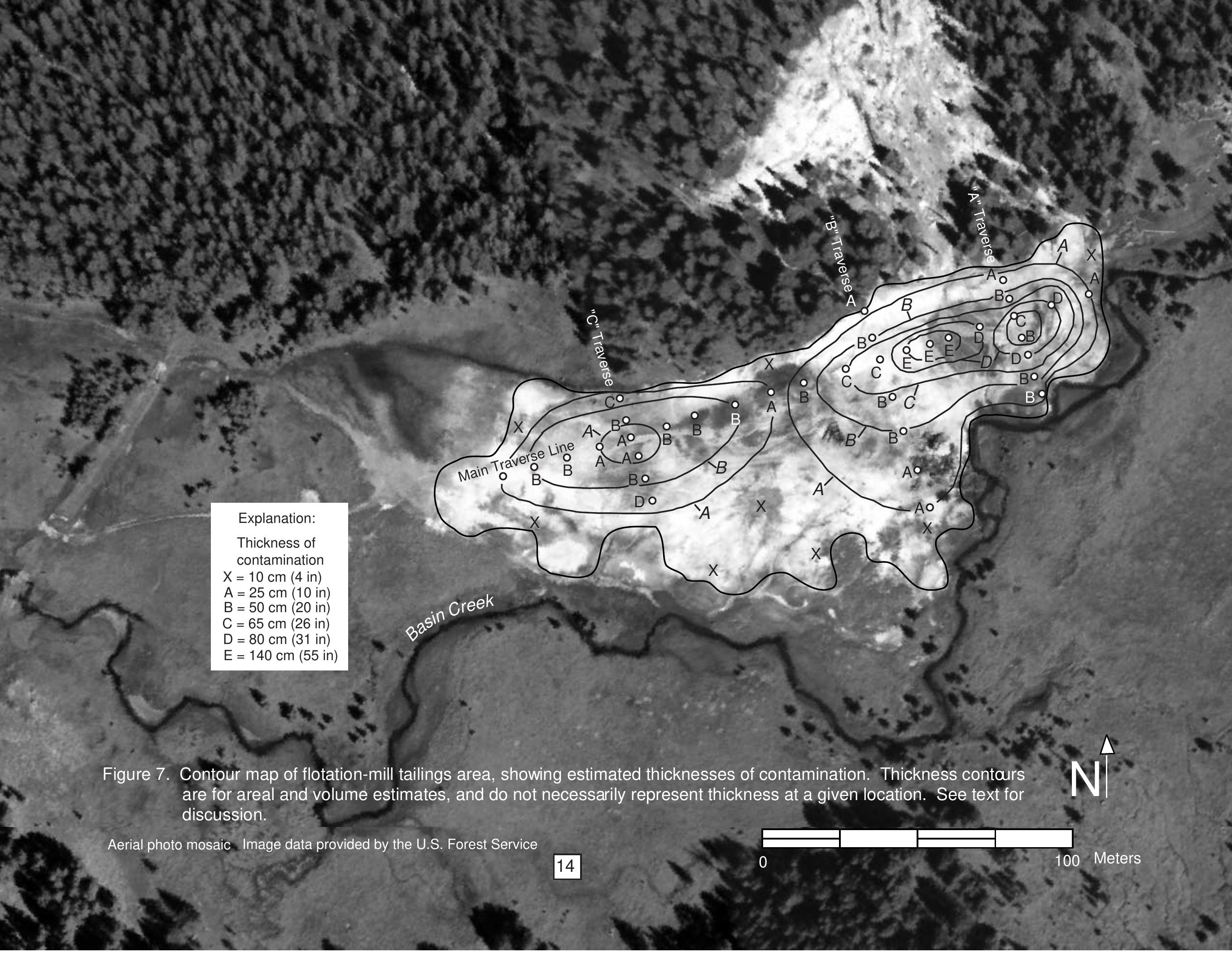


probably carry more material to the creek west of traverse B. The concentrations of arsenic and lead are significantly higher from 97-BMS-101-B7 downstream to 96-BM-136.

Analyses of trace elements from the warm $2 \mathrm{M} \mathrm{HCl}-1 \% \mathrm{H}_{2} \mathrm{O}_{2}$ leach (table 7) show that much of the trace-element content in the bed sediments is in the leachable phase. This partial extraction releases metals associated with hydrous amorphous iron- and manganese-oxide coatings and colloidal particles incorporated into the bed sediments (Church and others, 1997). The extraction solution only weakly attacks primary sulfide grains with the exception of galena $(\mathrm{PbS})$, which is readily soluble in warm $2 \mathrm{M} \mathrm{HCl}$. The ratio of leachable to total concentrations for the metals reveals information about the mineral phases harboring and transporting the different metals in the bed sediments.

Examination of the individual elements from the six bed sediments reveals the following

1. Silver in the leachable phase comprises $40 \%$ to $90 \%$ of the total.

2. Arsenic in the leachable phase comprises $45 \%$ to $88 \%$ of the total arsenic.

3. Cadmium in the leachable phase comprises up to $100 \%$ of the total cadmium.

4. Copper in the leachable phase comprises $50 \%$ to $90 \%$ of the total.

5. Lead in the leachable phase comprises $70 \%$ to $100 \%$ of the total lead (although since the leach solubilizes primary galena, one cannot differentiate between primary-mineral lead and adsorbed lead.

6. Zinc in the leachable phase comprises $60 \%$ to $83 \%$ of the total zinc.

The leachability of trace elements, as released by the $2 \mathrm{M} \mathrm{HCl}-1 \% \mathrm{H}_{2} \mathrm{O}_{2}$ leach, from the bed sediments does not directly correspond to the downward mobility of these same elements in the flotation tailings cores. The $2 \mathrm{M} \mathrm{HCl}-1 \% \mathrm{H}_{2} \mathrm{O}_{2}$ solution is more effective in its ability to leach trace elements than the pore waters encountered in the tailings. Evidence of this is reflected by the relative downward immobility of silver and lead in the tailings but high leachability of these two elements when subjected to the $2 \mathrm{M} \mathrm{HCl}-1 \% \mathrm{H}_{2} \mathrm{O}_{2}$ leach. The leachability data of the bed sediments reflect the process of element sorption onto colloids and iron- and manganese-hydroxides, and subsequent settling and incorporation into bed sediments. This process helps describe elemental transport in bed sediments downstream, as discussed in Church and others (1997). The $\mathrm{pH}$ of tailings pore waters was as low as 3.5; dissolved oxygen was as low as $4 \mathrm{ppm}$. Otherwise, the nature of the pore water and its ability to leach, compared to the $2 \mathrm{M} \mathrm{HCl}-1 \% \mathrm{H}_{2} \mathrm{O}_{2}$ leach, was not determined. A pore-water sample from the four-footdeep trench (core site 98-BMF-102) at a depth of about three and a half feet, in gray, unoxidized tailings contained high concentrations of iron $(1,700 \mathrm{mg} / \mathrm{L})$, copper $(130 \mathrm{mg} / \mathrm{L})$, zinc $(420 \mathrm{mg} / \mathrm{L})$, and arsenic $(620 \mathrm{mg} / \mathrm{L})$. The lead concentration was $3,600 \mu \mathrm{g} / \mathrm{L}$, cadmium was $2,000 \mu \mathrm{g} / \mathrm{L}$, and silver was low at only $7.5 \mu \mathrm{g} / \mathrm{L}$. Thus, trace-element downward migration in the tailings pore waters is significant, but the magnitude and processes involved cannot be estimated by or compared with the $2 \mathrm{M} \mathrm{HCl}-1 \%$ $\mathrm{H}_{2} \mathrm{O}_{2}$ leach.

\section{Summary and conclusions}

Analytical results for 35 cores collected from flotation tailings from the Buckeye mill tailings site reveal that six environmentally important trace elements ( $\mathrm{Ag}, \mathrm{As}, \mathrm{Cd}, \mathrm{Cu}, \mathrm{Pb}$ and $\mathrm{Zn}$ ) are present at high concentrations. Contamination from five of the six trace elements (not including silver) persists to a 
depth of about $30 \mathrm{~cm}$ ( $1 \mathrm{ft}$.) below the tailings, as a result of downward migration into the underlying pre-mining material, mostly quartz monzonite-derived micaceous sand. Calculations based on the contamination depths and areal extent indicate that the total volume of contaminated material (tailings and underlying contaminated sandy material) is about $3,800 \mathrm{~m}^{3}$ (5,000 cubic yards), or about 8,400 metric tons. Analyses of six bed sediments from Basin Creek show significant influence from the mill tailings. The greatest impact on the bed-sediment chemistry occurs downstream of the eastern half of the tailings, where runoff from storms and spring snowmelt enters the creek from surface drainage channels. Partial extractions of the bed sediments reveal that a significant fraction (40\% to 100\%) of the named trace elements are present in phases solubilized by a warm $2 \mathrm{M} \mathrm{HCl}-1 \% \mathrm{H}_{2} \mathrm{O}_{2}$ leach. These leachable phases include settled colloids and hydrous amorphous iron- and manganese-hydroxide coatings of bed-sediment particles. 


\section{REFERENCES CITED}

Briggs, P.H., 1996, Forty elements by inductively coupled-plasma atomic emission spectrometry, in Arbogast, B.F., ed., Analytical methods manual for the Mineral Resources Program, U.S. Geological Survey Open-File Report 96-525, p. 77-94.

Buxton, H.T., Nimick, D.A., von Guerard, P., Church, S.E., Frazier, A., Gray, J.R., Lipin, B.R., Marsh, S.P. Woodward, D., Kimball, B., Finger, S., Ischinger, L., Fordham, J.C., Power, M.S., Bunck, C., and Jones, J.W., 1997, A science-based Watershed strategy to support effective remediation of abandoned mine lands: in Fourth International Conference on Acid Rock Drainage Proceedings, v. IV, Vancouver, B.C. Canada, May 31-June 5, 1997, p. 1869-1880.

Chao, T.T., 1984, Use of partial dissolution techniques in geochemical exploration: Journal of Geochemical Exploration, v. 20, p. 101-135.

Church, S.E., Mosier, E.L., and Motooka, J.M., 1987, Mineralogical basis for the interpretation of multielement (ICP-AES), oxalic acid, and aqua-regia partial digestions of stream sediments for reconnaissance exploration geochemistry: Journal of Geochemical Exploration, v. 29, p. 207-233.

Church, S.E., Holmes, C.E., Briggs, P.H., Vaughn, R.B., Cathcart, James and Marot, Margaret, 1993, Geochemical and lead-isotope data from stream and lake sediments, and cores from the upper Arkansas River drainage: Effects of mining at Leadville Colorado on heavymetal concentrations in the Arkansas River: U.S. Geological Survey Open-File Report 93-534, $61 \mathrm{p}$.

Church, S.E., Kimball, B.A., Fey, D.L., Ferderer, D.A., Yager, T.J., and Vaughn, R.B., 1997, Source, transport, and partitioning of metals between water, colloids, and bed sediments of the Animas River, Colorado: U.S. Geological Survey Open-File Report 97-151, 135 p.

Crock, J.G., Lichte, F.E., and Briggs, 1983, Determination of elements in National Bureau of Standards geologic reference materials SRM 278 obsidian and SRM 688 basalt by inductively coupled plasma-atomic emission spectroscopy: Geostandards Newsletter, v. 7, p. 335-340.

Desborough , G.A., and Fey, D.L., 1997, Preliminary characterization of acid-generating potential and toxic metal solubility of some abandoned metal-mining related wastes in the Boulder River headwaters, northern Jefferson County, Montana: U.S. Geological Survey Open File Report 97-478, $21 \mathrm{p}$.

Fey, D.L., and Church, S.E., 1998. Analytical results for 42 fluvial tailings cores and 7 stream sediment samples from High Ore Creek, northern Jefferson County, Montana, U.S. Geological Survey Open File Report 98-215, 49 p.

Fortescue, J.A.C., 1992, Landscape geochemistry: retrospect and prospect--1990: Applied Geochemistry, v. 7, p. 1-54.

Metesh, J., Lonn, J., Duaime, T., and Wintergerst, R., 1994, Abandoned-inactive mines program Deer Lodge National Forest, Volume I-Basin Creek Drainage: Montana Bureau of Mines and Geology Open-File Report 321, 131 p.

National Institute of Standards and Technology (NIST), 1993a, Certificate of Analysis Standard Reference Material 2704, Buffalo River Sediment. 
, 1993b, Certificate of Analysis Standard Reference Material 2709, San Joaquin Soil. , 1993c, Certificate of Analysis Standard Reference Material 2711, Montana Soil.

Rossillon, M., and Haynes, T., 1999, Basin Creek Mine Reclamation Heritage Resource Inventory 1998 Volume I. Renewable Technologies, Inc., Butte, Montana, 126 p. Submitted to Beaverhead- Deerlodge National Forest, Dillon, Montana

Wilson, S. A., Briggs, P.H., Mee, J.S., and Siems, D.F., 1994, Determinations of thirty-two major and trace elements in three NIST soil SRMs using ICP-AES and WDXRF: Geostandards Newsletter, v. 18, p. 85-89. 


\section{Appendix}

TABLE A1 Comparison of contract laboratory results with NIST values for SRM-2704

\begin{tabular}{|c|c|c|c|c|c|}
\hline SRM-2704 & $\mathrm{n}=20$ & & & & \\
\hline Element & $\begin{array}{r}\text { observed } \\
\text { conc. }\end{array}$ & $\begin{array}{r}\text { observed } \\
\% \text { RSD }\end{array}$ & $\begin{array}{l}\text { NIST } \\
\text { value }\end{array}$ & $\begin{array}{l}\text { NIST } \\
\text { C.I. }{ }^{*}\end{array}$ & $\begin{array}{r}\text { PERCENT } \\
\text { RECOVERY }\end{array}$ \\
\hline Al $\%$ & 5.71 & 2.8 & 6.11 & 0.16 & 93 \\
\hline $\mathrm{Ca} \%$ & 2.61 & 5.6 & 2.6 & 0.03 & 100 \\
\hline $\mathrm{Fe} \%$ & 3.73 & 3.9 & 4.11 & 0.10 & 91 \\
\hline K \% & 1.84 & 4.9 & 2.00 & 0.04 & 92 \\
\hline $\mathrm{Mg} \%$ & 1.12 & 3.3 & 1.2 & 0.02 & 93 \\
\hline $\mathrm{Na} \%$ & 0.56 & 4.8 & 0.55 & 0.014 & 102 \\
\hline P \% & 0.08 & 8.1 & 0.099 & 0.003 & 81 \\
\hline $\mathrm{Ti} \%$ & 0.33 & 5.3 & 0.457 & 0.018 & 72 \\
\hline $\mathrm{Mn}, \mathrm{ppm}$ & 550 & 4.3 & 555 & 19 & 99 \\
\hline $\mathrm{Ag}, \mathrm{ppm}$ & $<2$ & & & & \\
\hline As, ppm & 33.6 & 60 & 23.4 & 0.8 & 144 \\
\hline $\mathrm{Ba}, \mathrm{ppm}$ & 405 & 14 & 414 & 12 & 98 \\
\hline $\mathrm{Cd}, \mathrm{ppm}$ & $<2$ & & 3.45 & 0.22 & \\
\hline $\mathrm{Ce}, \mathrm{ppm}$ & 62 & 3.7 & 72 & & 86 \\
\hline Co, ppm & 10.9 & 0.7 & 14 & 0.6 & 78 \\
\hline $\mathrm{Cr}, \mathrm{ppm}$ & 76.6 & 20 & 135 & 5 & 57 \\
\hline Cu, ppm & 88.9 & 5.5 & 98.6 & 5 & 90 \\
\hline Ga, ppm & 10.9 & 3.5 & 15 & & 73 \\
\hline La, ppm & 29.2 & 0.8 & 29 & & 101 \\
\hline $\mathrm{Li}, \mathrm{ppm}$ & 39.5 & 1.3 & 50 & & 79 \\
\hline Mo, ppm & 3.6 & 0.5 & & & \\
\hline $\mathrm{Nb}, \mathrm{ppm}$ & 6.2 & 3.8 & & & \\
\hline $\mathrm{Nd}, \mathrm{ppm}$ & 28.9 & 1.3 & & & \\
\hline $\mathrm{Ni}, \mathrm{ppm}$ & 38.4 & 1.8 & 44 & 3 & 87 \\
\hline $\mathrm{Pb}, \mathrm{ppm}$ & 161 & 20 & 161 & 17 & 100 \\
\hline Sc, ppm & 10.6 & 0.5 & 12 & & 88 \\
\hline Sr, ppm & 125 & 4.5 & 130 & & 96 \\
\hline Th, ppm & 7.4 & 2 & 9.2 & & 80 \\
\hline $\mathrm{V}, \mathrm{ppm}$ & 88.4 & 9.8 & 95 & 4 & 93 \\
\hline Y, ppm & 18.9 & 0.9 & & & \\
\hline Yb, ppm & 2.1 & 0.3 & 2.8 & & 75 \\
\hline Zn, ppm & 375 & 22 & 438 & 12 & 86 \\
\hline
\end{tabular}

* $95 \%$ confidence interval

This table shows the results for twenty analyses for SRM-2704 submitted as blind samples to the contract laboratory. 
TABLE A2 Comparison of contract laboratory results with NIST values for SRM-2709

\begin{tabular}{|c|c|c|c|c|c|}
\hline SRM-2709 & $n=20$ & & & & \\
\hline & observed & observed & NIST & NIST & PERCENT \\
\hline Element & conc. & $\%$ RSD & value & C.I. ${ }^{*}$ & RECOVERY \\
\hline Al $\%$ & 7.02 & 3.4 & 7.5 & 0.06 & 94 \\
\hline $\mathrm{Ca} \%$ & 1.82 & 3.4 & 1.89 & 0.05 & 96 \\
\hline $\mathrm{Fe} \%$ & 3.26 & 3.4 & 3.50 & 0.11 & 93 \\
\hline K \% & 1.89 & 5.3 & 2.03 & 0.06 & 93 \\
\hline $\mathrm{Mg} \%$ & 1.41 & 5.1 & 1.51 & 0.05 & 93 \\
\hline $\mathrm{Na} \%$ & 1.11 & 6.5 & 1.16 & 0.03 & 96 \\
\hline P \% & 0.05 & 11 & 0.062 & 0.005 & 81 \\
\hline $\mathrm{Ti} \%$ & 0.35 & 2.8 & 0.342 & 0.024 & 102 \\
\hline $\mathrm{Mn}, \mathrm{ppm}$ & 482 & 4.80 & 538 & 17 & 90 \\
\hline $\mathrm{Ag}, \mathrm{ppm}$ & $<2$ & & 0.41 & 0.03 & \\
\hline As, ppm & 27.7 & 14 & 17.7 & 0.8 & 156 \\
\hline $\mathrm{Ba}, \mathrm{ppm}$ & 903 & 24 & 968 & 40 & 93 \\
\hline $\mathrm{Cd}, \mathrm{ppm}$ & $<2$ & & 0.38 & 0.01 & \\
\hline $\mathrm{Ce}, \mathrm{ppm}$ & 42.6 & 2.1 & 42 & & 101 \\
\hline Co, ppm & 10.6 & 0.7 & 13.4 & 0.7 & 79 \\
\hline $\mathrm{Cr}, \mathrm{ppm}$ & 41.2 & 16 & 130 & 4 & 32 \\
\hline $\mathrm{Cu}, \mathrm{ppm}$ & 30.1 & 1.3 & 34.6 & 0.7 & 87 \\
\hline Ga, ppm & 14.2 & & 14 & & 101 \\
\hline La, ppm & 21.7 & 1.2 & 23 & & 94 \\
\hline Li, ppm & 47.5 & 1.3 & 50 & & 95 \\
\hline Mo, ppm & $<2$ & & 2 & & \\
\hline $\mathrm{Nb}, \mathrm{ppm}$ & 8.1 & 4.6 & & & \\
\hline $\mathrm{Nd}, \mathrm{ppm}$ & 18.5 & 0.7 & 19 & & 97 \\
\hline $\mathrm{Ni}, \mathrm{ppm}$ & 72.5 & 2.5 & 88 & 5 & 82 \\
\hline $\mathrm{Pb}, \mathrm{ppm}$ & 30 & 12 & 18.9 & 0.5 & 159 \\
\hline Sc, ppm & 11 & 0.3 & 12 & & 92 \\
\hline Sr, ppm & 215 & 7.8 & 231 & 2 & 93 \\
\hline Th, ppm & 9.8 & 0.8 & 11 & & 89 \\
\hline V, ppm & 108 & 8.3 & 112 & 5 & 96 \\
\hline $\mathrm{Y}, \mathrm{ppm}$ & 13.4 & 0.5 & 18 & & 74 \\
\hline Yb, ppm & 1.8 & 0.2 & 1.6 & & 113 \\
\hline $\mathrm{Zn}, \mathrm{ppm}$ & 95.6 & 8.6 & 106 & 3 & 90 \\
\hline
\end{tabular}

\section{* $95 \%$ confidence interval}

This table shows the results for twenty analyses for SRM-2709 submitted as blind samples to the contract laboratory. 
TABLE A3 Comparison of contract laboratory results with NIST values for SRM-2711

\begin{tabular}{|c|c|c|c|c|c|}
\hline SRM-2711 & $\mathrm{n}=20$ & & & & \\
\hline Element & $\begin{array}{c}\text { observed } \\
\text { conc. }\end{array}$ & $\begin{array}{r}\text { observed } \\
\% \text { RSD }\end{array}$ & $\begin{array}{l}\text { NIST } \\
\text { value }\end{array}$ & $\begin{array}{l}\text { NIST } \\
\text { C.I. }{ }^{*}\end{array}$ & $\begin{array}{r}\text { PERCENT } \\
\text { RECOVERY }\end{array}$ \\
\hline Al $\%$ & 6.33 & 2.79 & 6.53 & 0.09 & 97 \\
\hline $\mathrm{Ca} \%$ & 2.81 & 3.73 & 2.88 & 0.08 & 98 \\
\hline $\mathrm{Fe} \%$ & 2.70 & 1.75 & 2.89 & 0.06 & 93 \\
\hline K \% & 2.34 & 4.76 & 2.45 & 0.08 & 95 \\
\hline $\mathrm{Mg} \mathrm{\%}$ & 0.99 & 3.62 & 1.05 & 0.03 & 94 \\
\hline $\mathrm{Na} \%$ & 1.16 & 4.30 & 1.14 & 0.03 & 101 \\
\hline P \% & 0.07 & 9.59 & 0.086 & 0.007 & 83 \\
\hline $\mathrm{Ti} \%$ & 0.29 & 1.69 & 0.306 & 0.023 & 96 \\
\hline $\mathrm{Mn}, \mathrm{ppm}$ & 575 & 4.1 & 638 & 28 & 90 \\
\hline $\mathrm{Ag}, \mathrm{ppm}$ & 4.5 & 15 & 4.63 & 0.39 & 97 \\
\hline As, ppm & 93.8 & 13 & 105 & 8 & 89 \\
\hline $\mathrm{Ba}, \mathrm{ppm}$ & 747 & 21 & 726 & 38 & 103 \\
\hline Cd, ppm & 34.6 & 4.9 & 41.7 & 0.25 & 83 \\
\hline $\mathrm{Ce}, \mathrm{ppm}$ & 70 & 6.6 & 69 & & 101 \\
\hline Co, ppm & 8 & 8.3 & 10 & & 80 \\
\hline $\mathrm{Cr}, \mathrm{ppm}$ & 18.1 & 34 & 47 & & 39 \\
\hline $\mathrm{Cu}, \mathrm{ppm}$ & 106 & 5.6 & 114 & 2 & 93 \\
\hline Ga, ppm & 13.7 & 18 & 15 & & 91 \\
\hline La, ppm & 37.2 & 4.7 & 40 & & 93 \\
\hline Li, ppm & 24.1 & 4.1 & & & \\
\hline Mo, ppm & $<2$ & & & & \\
\hline $\mathrm{Nb}, \mathrm{ppm}$ & 15 & 21 & & & \\
\hline $\mathrm{Nd}, \mathrm{ppm}$ & 31.1 & 2.9 & 31 & & 100 \\
\hline $\mathrm{Ni}, \mathrm{ppm}$ & 17.8 & 4 & 20.6 & 1.1 & 86 \\
\hline $\mathrm{Pb}, \mathrm{ppm}$ & 1060 & 3.8 & 1162 & 31 & 91 \\
\hline Sc, ppm & 8.8 & 4.2 & 9 & & 98 \\
\hline Sr, ppm & 236 & 2.3 & 245 & 0.7 & 96 \\
\hline Th, ppm & 12.1 & 12 & 14 & & 86 \\
\hline V, ppm & 79.4 & 7.9 & 81.6 & 2.9 & 97 \\
\hline Y, ppm & 23 & 4.3 & 25 & & 92 \\
\hline Yb, ppm & 2.9 & 11 & 2.7 & & 107 \\
\hline Zn, ppm & 304 & 3.9 & 350 & 4.8 & 87 \\
\hline
\end{tabular}

* $95 \%$ confidence interval

This table shows the results for twenty analyses for SRM-2711 submitted as blind samples to the contract laboratory. 
TABLE A4 Comparison of USGS laboratory results with NIST values for SRM-2704

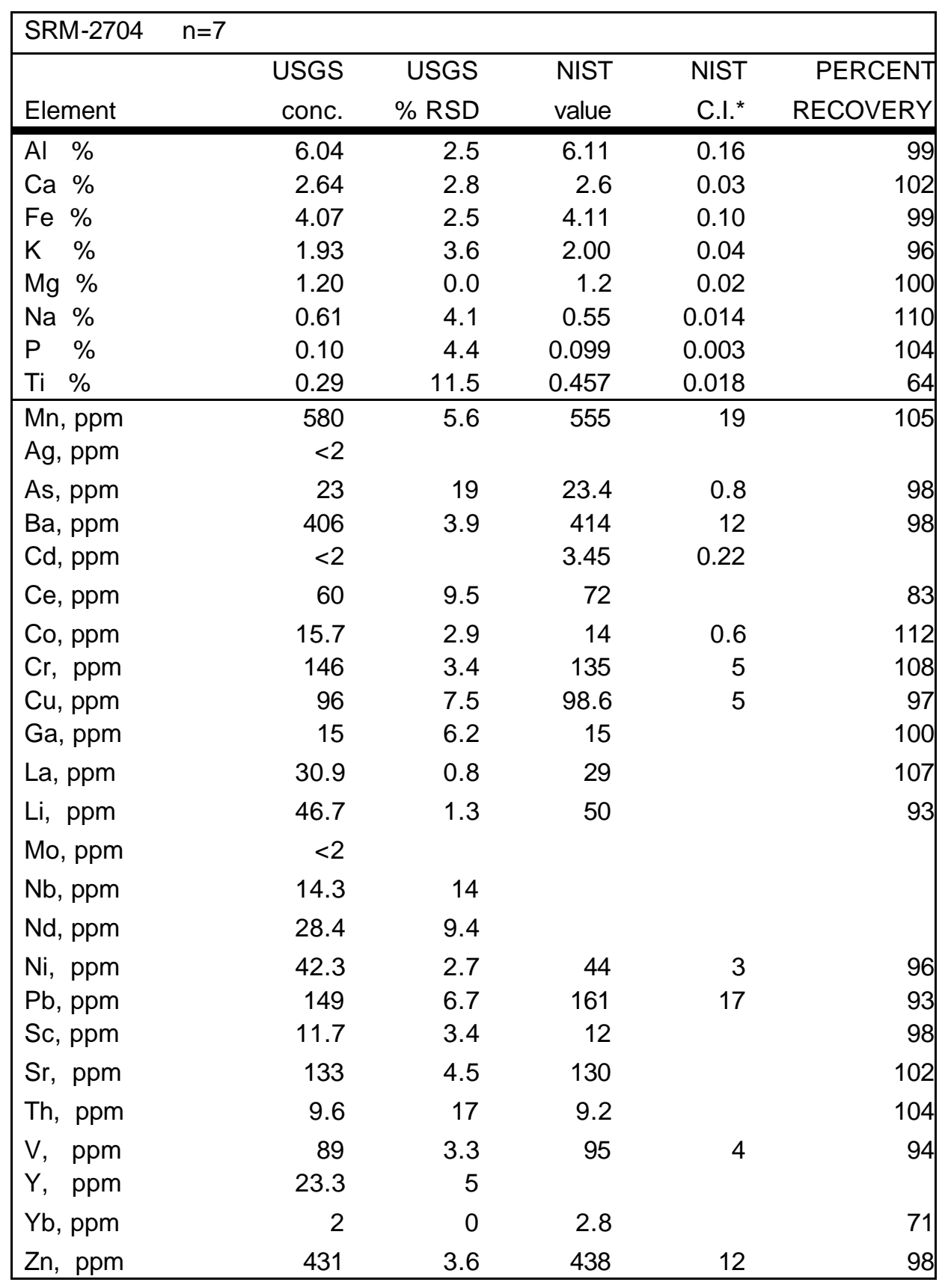

* $95 \%$ confidence interval

This table shows the results for seven analyses for SRM-2704 analyzed in-house in the USGS analytical laboratories in Denver, Co. 
TABLE A5 Comparison of USGS laboratory results with NIST values for SRM-2709

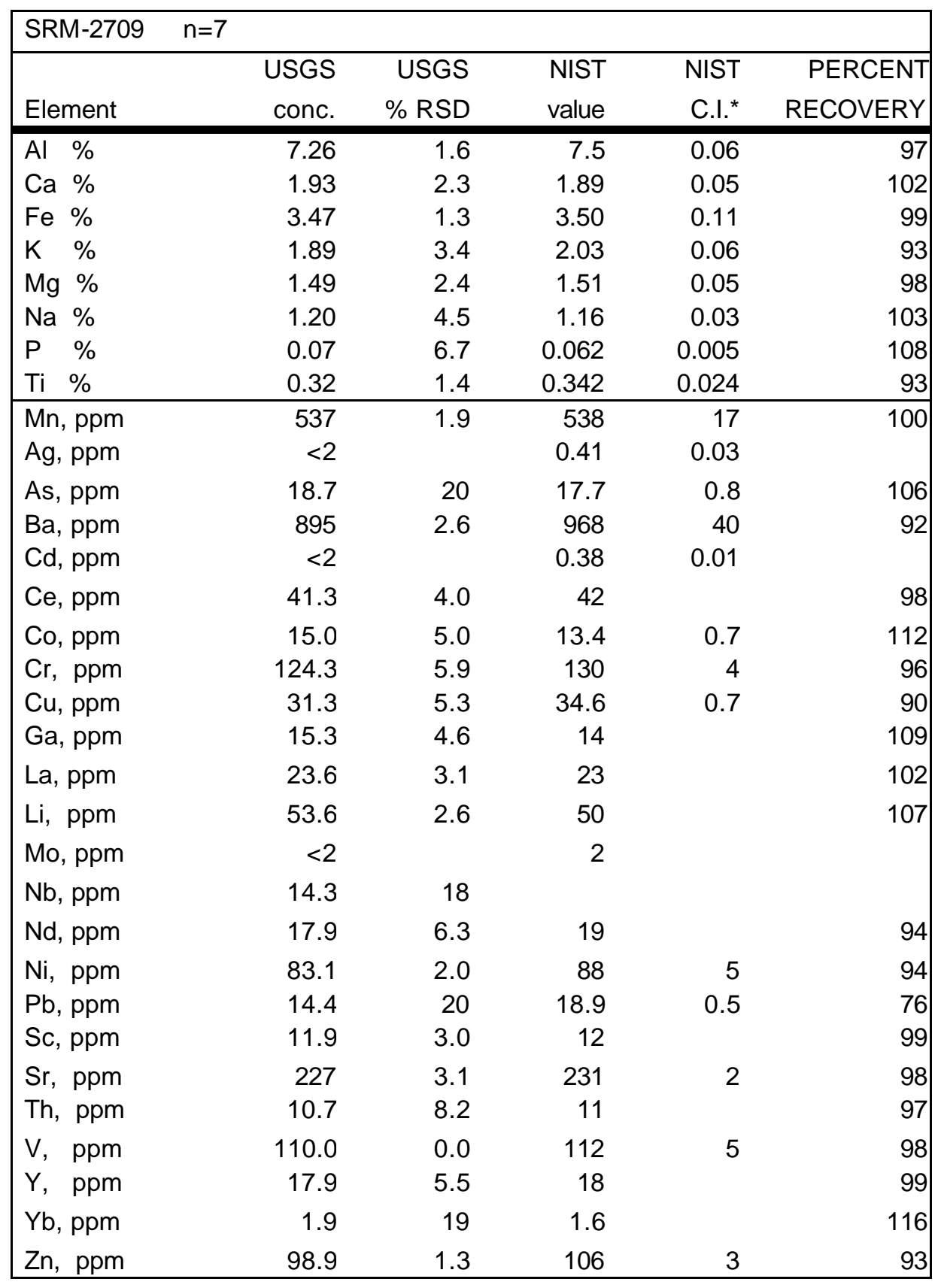

* $95 \%$ confidence interval

This table shows the results for seven analyses for SRM-2709 analyzed in-house in the USGS analytical laboratories in Denver, Co. 
TABLE A6 Comparison of USGS laboratory results with NIST values for SRM-2711

\begin{tabular}{|c|c|c|c|c|c|}
\hline SRM-2711 & $n=7$ & & & & \\
\hline & USGS & USGS & NIST & NIST & PERCENT \\
\hline Element & conc. & $\%$ RSD & value & C.I. ${ }^{*}$ & RECOVERY \\
\hline Al $\%$ & 6.39 & 3.3 & 6.53 & 0.09 & 98 \\
\hline $\mathrm{Ca} \%$ & 2.93 & 3.5 & 2.88 & 0.08 & 102 \\
\hline $\mathrm{Fe} \%$ & 2.86 & 3.2 & 2.89 & 0.06 & 99 \\
\hline K \% & 2.34 & 6.0 & 2.45 & 0.08 & 96 \\
\hline $\mathrm{Mg} \mathrm{\%}$ & 1.04 & 4.7 & 1.05 & 0.03 & 99 \\
\hline $\mathrm{Na} \%$ & 1.21 & 5.3 & 1.14 & 0.03 & 107 \\
\hline P $\%$ & 0.08 & 5.9 & 0.086 & 0.007 & 98 \\
\hline $\mathrm{Ti} \%$ & 0.26 & 3.5 & 0.306 & 0.023 & 84 \\
\hline $\mathrm{Mn}, \mathrm{ppm}$ & 677 & 14 & 638 & 28 & 106 \\
\hline $\mathrm{Ag}, \mathrm{ppm}$ & 3.6 & 14 & 4.63 & 0.39 & 77 \\
\hline As, ppm & 100 & 6.6 & 105 & 8 & 95 \\
\hline $\mathrm{Ba}, \mathrm{ppm}$ & 688 & 4.7 & 726 & 38 & 95 \\
\hline $\mathrm{Cd}, \mathrm{ppm}$ & 37.3 & 1.9 & 41.7 & 0.25 & 89 \\
\hline $\mathrm{Ce}, \mathrm{ppm}$ & 67.4 & 4.1 & 69 & & 98 \\
\hline Co, ppm & 11.6 & 4.3 & 10 & & 116 \\
\hline $\mathrm{Cr}, \mathrm{ppm}$ & 47.0 & 3.4 & 47 & & 100 \\
\hline Cu, ppm & 108 & 6.5 & 114 & 2 & 95 \\
\hline $\mathrm{Ga}, \mathrm{ppm}$ & 16.0 & 6.7 & 15 & & 107 \\
\hline La, ppm & 37.9 & 3.8 & 40 & & 95 \\
\hline $\mathrm{Li}, \quad \mathrm{ppm}$ & 26.7 & 4.8 & & & \\
\hline Mo, ppm & $<2$ & & & & \\
\hline $\mathrm{Nb}, \mathrm{ppm}$ & 17.0 & 31 & & & \\
\hline $\mathrm{Nd}, \mathrm{ppm}$ & 28.9 & 4.3 & 31 & & 93 \\
\hline $\mathrm{Ni}, \mathrm{ppm}$ & 19.6 & 2.5 & 20.6 & 1.1 & 95 \\
\hline $\mathrm{Pb}, \mathrm{ppm}$ & 1070 & 6.7 & 1162 & 31 & 92 \\
\hline Sc, ppm & 9.3 & 4.9 & 9 & & 103 \\
\hline Sr, ppm & 244 & 3.7 & 245 & 0.7 & 100 \\
\hline Th, ppm & 13.9 & 4.6 & 14 & & 99 \\
\hline V, ppm & 77.6 & 2.7 & 81.6 & 2.9 & 95 \\
\hline Y, ppm & 26.9 & 5.0 & 25 & & 107 \\
\hline Yb, ppm & 2.7 & 17 & 2.7 & & 101 \\
\hline Zn, ppm & 353 & 5.4 & 350 & 4.8 & 101 \\
\hline
\end{tabular}

$* 95 \%$ confidence interval

This table shows the results for seven analyses for SRM-2711 analyzed in-house in the USGS analytical laboratories in Denver, Co. 
TABLE A7 ICP-AES elements and their limits of determination

\begin{tabular}{|lccc|}
\hline & & Total Digestion & $\mathrm{HCl}_{2} \mathrm{H}_{2} \mathrm{O}_{2}$ Leach \\
Element & Symbol & Procedure & Procedure \\
\hline Aluminum & $\mathrm{Al}$ & $.005 \%$ & $30 \mathrm{ppm}$ \\
Calcium & $\mathrm{Ca}$ & $.005 \%$ & $30 \mathrm{ppm}$ \\
Iron & $\mathrm{Fe}$ & $.005 \%$ & $30 \mathrm{ppm}$ \\
Potassium & $\mathrm{K}$ & $.01 \%$ & $30 \mathrm{ppm}$ \\
Magnesium & $\mathrm{Mg}$ & $.005 \%$ & $30 \mathrm{ppm}$ \\
Sodium & $\mathrm{Na}$ & $.005 \%$ & $30 \mathrm{ppm}$ \\
Phosphorous & $\mathrm{P}$ & $.005 \%$ & $30 \mathrm{ppm}$ \\
Silicon & $\mathrm{Si}$ & -- & $30 \mathrm{ppm}$ \\
Titanium & $\mathrm{Ti}$ & $.005 \%$ & $30 \mathrm{ppm}$ \\
\hline Manganese & $\mathrm{Mn}$ & $4 \mathrm{ppm}$ & $1.2 \mathrm{ppm}$ \\
Silver & $\mathrm{Ag}$ & $2 \mathrm{ppm}$ & $1.2 \mathrm{ppm}$ \\
Arsenic & $\mathrm{As}$ & $10 \mathrm{ppm}$ & $6 \mathrm{ppm}$ \\
Barium & $\mathrm{Ba}$ & $1 \mathrm{ppm}$ & $.6 \mathrm{ppm}$ \\
Cadmium & $\mathrm{Cd}$ & $2 \mathrm{ppm}$ & $1.2 \mathrm{ppm}$ \\
Cerium & $\mathrm{Ce}$ & $4 \mathrm{ppm}$ & $2.4 \mathrm{ppm}$ \\
Cobalt & $\mathrm{Co}$ & $1 \mathrm{ppm}$ & $.6 \mathrm{ppm}$ \\
Chromium & $\mathrm{Cr}$ & $1 \mathrm{ppm}$ & $.6 \mathrm{ppm}$ \\
Copper & $\mathrm{Cu}$ & $1 \mathrm{ppm}$ & $.6 \mathrm{ppm}$ \\
Gallium & $\mathrm{Ga}$ & $4 \mathrm{ppm}$ & -- \\
Lanthanum & $\mathrm{La}$ & $2 \mathrm{ppm}$ & $1.2 \mathrm{ppm}$ \\
Lithium & $\mathrm{Li}$ & $2 \mathrm{ppm}$ & $2 \mathrm{ppm}$ \\
Molybdenum & $\mathrm{Mo}$ & $2 \mathrm{ppm}$ & $1.2 \mathrm{ppm}$ \\
Niobium & $\mathrm{Nb}$ & $4 \mathrm{ppm}$ & -- \\
Neodymium & $\mathrm{Nd}$ & $4 \mathrm{ppm}$ & -- \\
Nickel & $\mathrm{Ni}$ & $2 \mathrm{ppm}$ & $1.2 \mathrm{ppm}$ \\
Lead & $\mathrm{Pb}$ & $4 \mathrm{ppm}$ & $2.4 \mathrm{ppm}$ \\
Antimony & $\mathrm{Sb}$ & -- & $3.0 \mathrm{ppm}$ \\
Scandium & $\mathrm{Sc}$ & $2 \mathrm{ppm}$ & -- \\
Strontium & $\mathrm{Sr}$ & $2 \mathrm{ppm}$ & $1.2 \mathrm{ppm}$ \\
Thorium & $\mathrm{Th}$ & $4 \mathrm{ppm}$ & $2 \mathrm{ppm}$ \\
Vanadium & $\mathrm{V}$ & $2 \mathrm{ppm}$ & $1.2 \mathrm{ppm}$ \\
Yttrium & $\mathrm{Y}$ & $2 \mathrm{ppm}$ & $1.2 \mathrm{ppm}$ \\
Ytterbium & $\mathrm{Yb}$ & $1 \mathrm{ppm}$ & -- \\
Zinc & $\mathrm{Zn}$ & $2 \mathrm{ppm}$ & $.6 \mathrm{ppm}$ \\
\hline
\end{tabular}




\section{Discussion of results in tables A1 through A6}

The ICP-AES analyses of the core samples were done by an outside laboratory; the analyses of the bed-sediment samples were done in-house in the USGS laboratories in Denver, Colorado. The results from the contract laboratory are generally acceptable, but there are several notable exceptions. The recoveries were somewhat less accurate, and the variances were higher for samples run by the contract laboratory than for those run by the USGS laboratory. Arsenic is biased high below 100 ppm, and somewhat low above 100 ppm, relative to recommended NIST values. No recommendations are presented to normalize these analyses; at the high As levels contained in the cores, the values are acceptable. Cobalt is biased low, but is not an important element in this study. Chromium recoveries are very low, due to incomplete digestion, and we do not recommend using the chromium analyses. Lead shows a high bias at levels below $50 \mathrm{ppm}$, is relatively neutral at several hundred ppm, and shows a low bias at levels greater than 1,000 ppm. The analyses are still quite acceptable for the purpose of this report. The values for titanium from both laboratories tend to be low, due to the refractory nature of titanium oxides, which may not be completely dissolved in this acid digestion. 